\title{
Energy Balance Data from Lactating Dairy Goats Offered Total Mixed Diets
}

\author{
Carlos Fernández*, Tamara Romero \\ Departamento de Ciencia Animal, Universitat Politècnica de València, Valencia, Spain \\ Email: *cjfernandez@dca.upv.es
}

How to cite this paper: Fernández, C. and Romero, T. (2019) Energy Balance Data from Lactating Dairy Goats Offered Total Mixed Diets. Open Journal of Animal Sciences, 9, 385-400.

https://doi.org/10.4236/ojas.2019.94031

Received: July 4, 2019

Accepted: August 23, 2019

Published: August 26, 2019

Copyright $\odot 2019$ by author(s) and Scientific Research Publishing Inc. This work is licensed under the Creative Commons Attribution International License (CC BY 4.0).

http://creativecommons.org/licenses/by/4.0/

\begin{abstract}
The objective of the study was to develop a univariate model for analyzing energy balance data from lactating goats at mid lactation and determine maintenance requirements and partial efficiencies of energy utilization. Energy balance data from eight studies involving lactating Murciano-Granadina goats fed total mixed diets, which accounted for a variation in metabolizable energy (MEI) intake, milk energy output (EI), and tissue energy balance, were used. The database included records obtained by indirect calorimetry. Data were adjusted with a mixed model that included the study as a random effect. Then, two multivariate linear models were obtained: metabolizable and net energy models. The metabolizable model was $\mathrm{MEI}=\beta_{0}+\beta_{2} \mathrm{El}+\beta_{3} \mathrm{Tg}+\beta_{4} \mathrm{Tl}+\varepsilon$ and the net energy model was $\mathrm{El}=\beta_{0}+\beta_{1} \mathrm{MEI}+\beta_{2} \mathrm{Tg}+\beta_{3} \mathrm{Tl}+\varepsilon$; where $\beta_{0}$, $\beta_{1}, \beta_{2}$ and $\beta_{3}$ were the parameters, Tg was tissue energy retention and $\mathrm{Tl}$ the milk energy derived from body stores. For a better fitted proposed model, net energy for maintenance (NEm) was $283 \mathrm{~kJ} / \mathrm{kg}$ of Body Weight ${ }^{0.75}(\mathrm{BW})$ per day, and the efficiency of utilization of ME for lactation $\left(\mathrm{k}_{\mathrm{l}}\right)$, body weight gain $\left(\mathrm{k}_{\mathrm{g}}\right)$ and body tissue mobilization for milk production $\left(\mathrm{k}_{\mathrm{t}}\right)$ were $62 \%, 83 \%$ and $78 \%$, respectively. Maintenance requirements and partial efficiencies for milk production and tissue energy mobilization were similar to the values proposed by INRA (2018). The increase in the efficiency of utilizing dietary energy for gain, compared with other feeding systems, was partially attributed to the stage of lactation, due to that goats were feeding at mid lactation.
\end{abstract}

\section{Keywords}

Energy Efficiency, Mixed Diets, Mixed Model, Lactating Goats

\section{Introduction}

The goat requires energy for self-organization, motion, harvesting food, maintenance, growth and/or milk production. Jørgensen [1] indicated that this is 
important to distinguish between two forms of energy: energy that can be accumulated to do work and the energy that cannot do work, and is lost as heat to the environment. As the world population continues to grow during this century, livestock must focus on production efficiency to provide an adequate food supply; for instance, milk and dairy foods.

The main feeding systems for dairy goats in the world are Agricultural and Food Research Council [2], National Research Council [3], the Small Ruminant Nutrition System [4] [5] and Institute Nationale Recherche Agronomique [6]. The last two systems included dairy goats' recommendation but the available information from Spanish dairy goats' breeds is still scarce. Energy requirements of ruminant have been studied via respiration calorimetry, comparative slaughter technique and feeding trials. Therefore, the different feeding systems compile a wide range of requirements due that different breeds, purposes (milk, meat and fiber) and energy requirements methodologies were combined. Data used in this study comes from the same breed and, the energy balance was quantified using open system indirect calorimetry techniques.

The metabolizable energy (ME) requirements for maintenance (MEm) and the efficiency of utilization of ME for lactation $\left(\mathrm{k}_{1}\right)$ are two key parameters in the calculation of the energy requirements of dairy goats. When the goat is in positive tissue energy balance, some of the ME intake (MEI) is being directed towards tissue energy retention ( $\mathrm{Tg}$ ) and $\mathrm{k}_{\mathrm{g}}$ is the efficiency of utilization of MEI for tissue energy gain. When the goat is in zero energy balance, all the MEI is being directed to maintenance and milk production. And when the goat is in negative energy balance, some of the milk energy is derived from body stores (Tl), being $k_{t}$ the efficiency of utilization of tissue energy for milk production.

These parameters have been estimated using a variety of modeling approaches for different livestock species. Historically in lactating cows, Moe et al. (1971) [7] proposed a multiple linear regression approach for estimating maintenance requirements and partial efficiencies based on the observation of dietary ME. Strathe et al. (2011) [8] proposed an energy function that generalized the model advocated by [7].

Some heat is lost during every energy transformation, and their quantification was some of the main objectives of the present study, combining indirect calorimetry data and linear mixed models. The objective of the present study is to collate data from energy balance studies with lactating dairy goats, and to fit Moe [7] and Strathe [8] mathematical functions to estimated parameters of energy metabolism in relation to milk production such us efficiency of utilization of ME for lactation $\left(k_{l}\right)$, body weight gain $\left(k_{g}\right)$, body tissue mobilization for milk production $\left(k_{t}\right)$ and MEm.

\section{Material and Methods}

\subsection{Animals and Feeding}

The experimental procedure was approved by the Animal Use and Care Com- 
mittee of the Universitat Politècnica de València (UPV, Spain) and followed the codes of practice for animals used in experimental works proposed by the European Union (2007) [9].

Data from eight energy balance experiments (three unpublished) conducted at the Experimental Farm of the UPV were used to develop the model [10] [11] [12] [13] [14]. All studies had shown the possibility to replace cereal grain with agricultural fibrous byproducts successfully. The trials encompassed a total of 267 observations from multiparous Murciano-Granadina goats; six studies in mid and two studies in mid-late lactation. The trial [10] replaced corn grain (37\%) with a blend of soy hulls and corn gluten feed and, alfalfa hay was used as forage (forage to concentrate ratio was 45:55) in lactating goats in mid lactation. [11] with lactating goats in mid lactation, studied the effect of replacing corn grain $(60 \%)$ with citrus pulp $(60 \%)$ or soy hulls $(60 \%)$ in a forage to concentrate ratio of 15:85. [12] replaced oats (38\%) with rice bran with lactating goats in mid-late lactation and alfalfa hay was the forage (35:65). [13] used the same concentrate and substituted alfalfa hay with maralfalfa hay in goats at mid-late lactation, being the forage to concentrate ratio of 40:60. [14], with goats in mid lactation and using alfalfa hay as forage (the forage to concentrate ratio was $33: 67)$, replaced barley grain (60\%) with fibrous byproducts such as orange pulp $(60 \%)$ or soy hulls $(60 \%)$. The other three unpublished studies, with lactating goats at mid lactation and forage to concentrate ratio of 40:60, replaced cereal grain with lemon pulp, beet pulp and olive pulp. Due to that these experiments were not published, more detailed were required, one replaced $35 \%$ of barley grain with lemon pulp and, to reach isoenergetic diets (11 MJ ME/kg dry matter (DM), on average) fat was added to lemon pulp diet $(2.5 \%$ and $4.1 \%$ of ether extract (EE) for cereal and lemon pulp, respectively). The neutral detergent fiber (NDF) ranged from $31 \%$ to $37 \%$ and crude protein (CP) was $18 \%$ on average. The second experiment replace $31 \%$ of corn with beet pulp and no fat was added (2.7\% and $1.9 \% \mathrm{EE}$ for corn and beet pulp, respectively), and the energy value was 13 and $12 \mathrm{MJ} \mathrm{ME} / \mathrm{kg} \mathrm{DM}$ ). Corn diet had 31\% NDF and mixed diet with beet pulp $56 \%$, and the $\mathrm{CP}$ content was $15 \%$ on average. The third experiment replaced $25 \%$ of barley with olive pulp and due that olive pulp has oil, the EE content of barley diet was $2.2 \%$ and olive pulp diet $4.3 \%$, therefore, the energy content was 11 and $12 \mathrm{MJ} \mathrm{ME} / \mathrm{kg} \mathrm{DM}$, respectively. The olive pulp mixed diet had greater NDF (33\%) than barley diet (28\%) and different CP content was observed as well; $18 \%$ and $15 \%$ for olive pulp and barley diets, respectively.

Therefore, goats were fed mixed diets with an average value of $17 \mathrm{MJ}$ of gross energy/kg DM (11 MJ ME/kg DM) and CP ranged from $14 \%$ to $18.7 \%$ DM basis. The NDF ranged from 23\% to 59\% (DM basis) and the starch content from $2 \%$ to $42 \%$ (DM basis). Due that some experiments replaced cereal with fibrous byproduct, in order to reach isoenergetic diets, lipids were added to some diets and the EE content ranged from $2 \%$ to $6 \%$. Intake was ad libitum with diets offered at $110 \%$ of consumption on the preceding few days and goats had free access to 
water. Half the daily ration was offered at 08:00 and the other half at 16:00, respectively.

Briefly, within each study, total energy intake and output of fecal, urinary and milk were recorded. ME intake was calculated as the difference between energy intake and the losses in feces, urine and methane. Energy recovered or loss was estimated by subtracting heat production and milk energy from ME intake. Heat production was measured by indirect calorimetry in open circuit respiration head hood system described by [15] [16]. Descriptive statistic of the range of calorimetric data included in database is summarized in Table 1.

\subsection{Studies Origin}

The database contained energy balance inputs and outputs from eight studies conducted at UPV, running between 2013 and 2016. In some instances, multiple observations were made on the same goat at different studies. We used a linear regression with fixed effect of study in an attempt to extract quantitative

Table 1. Summary statistics of the calorimetry data $(n=267)$.

\begin{tabular}{|c|c|c|c|c|}
\hline Item & Mean & Standard deviation & Minimum & Maximum \\
\hline \multicolumn{5}{|c|}{ Diet composition, \% DM } \\
\hline DM percentage & 88.6 & 0.87 & 87.5 & 90.2 \\
\hline Ash & 8.1 & 0.99 & 6.9 & 10.7 \\
\hline $\mathrm{CP}$ & 16.5 & 2.17 & 14.5 & 18.5 \\
\hline $\mathrm{NDF}$ & 39.8 & 9.66 & 22.8 & 59.0 \\
\hline $\mathrm{EE}$ & 3.8 & 1.1 & 1.9 & 5.7 \\
\hline Starch & 18.4 & 13.02 & 1.5 & 41.6 \\
\hline $\mathrm{ME}$ & 11 & 0.69 & 9 & 13 \\
\hline \multicolumn{5}{|l|}{ Animal } \\
\hline Body weight, $\mathrm{kg}$ & 44 & 4.7 & 32 & 61 \\
\hline DMI, kg/d & 1.734 & 0.225 & 1.231 & 2.287 \\
\hline Milk yield, $\mathrm{kg} / \mathrm{d}$ & 1.86 & 0.31 & 0.81 & 2.61 \\
\hline \multicolumn{5}{|c|}{ Energy measurements, $\mathrm{kJ} / \mathrm{kg} \mathrm{BW} 0.75$} \\
\hline Gross energy & 1751 & 226.0 & 1168 & 2414 \\
\hline Fecal energy & 493 & 126.6 & 249 & 794 \\
\hline Urinary energy & 47 & 15.9 & 24 & 158 \\
\hline Methane & 86 & 26.7 & 13 & 177 \\
\hline ME intake & 1124 & 153.7 & 784 & 1619 \\
\hline Heat production & 704 & 93.5 & 522 & 975 \\
\hline Milk energy & 392 & 65.5 & 167 & 589 \\
\hline Retained energy & 28 & 57.6 & -153 & 197 \\
\hline
\end{tabular}

$\mathrm{DM}=$ dry matter; $\mathrm{CP}=$ crude protein of diet; $\mathrm{NDF}=$ neutral detergent fiber; $\mathrm{EE}=$ ether extract; $\mathrm{ME}=$ metabolizable energy; $\mathrm{BW}=$ body weight. 
relationships that best explain the observations.

$$
Y_{i j}=\partial+S_{i}+X_{i j}+\varepsilon_{i j}
$$

where $Y_{i j}$ was the dependent variable, $\partial$ was the intercept, $S_{i}$ was the fixed effect of $i^{\text {th }}$ study, $X_{i j}$ was the value of the continuous predictor variable of the $f^{\text {th }}$ observation in the $i^{\text {th }}$ study and $\varepsilon_{i j}$ was the residual deviation of the $f^{\text {th }}$ observation in the $i^{\text {th }}$ study. The continuous predictor variable used was the ratio energy in milk to MEI, both expressed in $\mathrm{kJ} / \mathrm{kg} \mathrm{BW} \mathrm{BW}^{0.75}$.

On the other hand, in order to avoid ignoring the fact that observations within a given study have more in common than observations across studies, random effect of study was used for mixed model analysis. The linear mixed model was detailed as follow:

$$
Y_{i j}=\partial+S_{i}+X_{i j}+\varepsilon_{i j}
$$

where $Y_{i j}$ was the dependent variable, $\partial$ was the intercept, $S_{i}$ was the random effect of $I^{\text {th }}$ study, $X_{i j}$ was the value of the continuous predictor variable, and $\varepsilon_{i j}$ was the residual deviation of the $f^{\text {th }}$ observation in the $i^{\text {th }}$ study. The continuous predictor variable used was the same as that above.

To account for the study effect, we have adjusted the individual measurements with respect to the study mean to remove variation among studies. Each residual was added to its corresponding Y predicted value to generate adjusted Y values [17] [18].

\subsection{Model Description}

Two models were used to describe energy utilization by lactating goats in the present work. Both models belong to the family of univariate models because the response represents a single energy trait. That is, the response variable was regressed on a set of independent variables. Historically, energy balance data from lactating dairy cows were analyzed using the classical linear regression approach of Moe [7]:

$$
\mathrm{MEI}=\alpha+\beta_{1} \mathrm{MBW}+\beta_{2} \mathrm{El}+\beta_{3} \mathrm{Tg}+\beta_{4} \mathrm{Tl}+\varepsilon
$$

where MEI, Tg and Tl were expressed in $\mathrm{kJ} / \mathrm{kg} \mathrm{BW}{ }^{0.75}$ per day, MBW was metabolic body weight ( $\mathrm{kg}$ of $\left.\mathrm{BW}^{0.75}\right)$ and, El was the energy in milk $\left(\mathrm{kJ} / \mathrm{kg} \mathrm{BW}^{0.75}\right.$ per day). The intercept a was the regression constant, which was assumed to represent the amount of MEI that was not attributable to any specific variable in the model. $\beta_{1}, \beta_{2}$, and $\beta_{3}$ represent the unit amount of ME required for maintenance, milk production and body gain, respectively, $\beta_{4}$ was the amount of dietary ME which is spared per unit of body tissue energy loss, and $\varepsilon$ was the error. The reciprocals $1 / \beta_{2}$ and $1 / \beta_{3}$ represent the efficiency of milk production $\left(k_{l}\right)$ and body gain $\left(k_{g}\right)$ from dietary MEI. The ratio $\beta_{4} / \beta_{2}$ represents the efficiency of use of body tissue for milk production $\left(k_{t}\right)$. Moe [7] reported that $\beta_{1}$ cannot be interpreted independent of the regression constant $(\alpha)$ and, it appears most logical to assign this amount of energy to the maintenance term:

$$
\mathrm{MEI}=\beta_{0}+\beta_{2} \mathrm{El}+\beta_{3} \mathrm{Tg}+\beta_{4} \mathrm{Tl}+\varepsilon
$$

The energy model function proposed by Strathe [8] was described as: 


$$
\mathrm{El}=\beta_{0}+\beta_{1} \mathrm{MEI}+\beta_{2} \mathrm{Tg}+\beta_{3} \mathrm{Tl}+\varepsilon
$$

where El, MEI, Tg and Tl were described above (kJ/kg BW $\mathrm{BW}^{0.75}$ per day). $\beta_{0}$ was the intercept and $\beta_{1}, \beta_{2}$ and $\beta_{3}$ were the parameters describing the change in El with unit change in MEI, Tg and Tl, respectively and $\varepsilon$ was the error. In this model, NEm $=-\beta_{0}, \mathrm{MEm}=-\left(\beta_{0} / \beta_{1}\right), k_{l}=\beta_{1}, k_{t}=\beta_{3}$, and $k_{g}=\left(\beta_{1} / \beta_{2}\right)$.

\subsection{Parameter Estimation and Goodness of Fit}

Univariate relationships between dependent and independent variables were fitted to data using $1 \mathrm{~m}$ and lme functions, from the library nlme, of the Statisitical package of $\mathrm{R}$ [19], considering goat as random in both models. In the Moe [7] model MEI was the dependent variable and, EI was the dependent variable by the [8] model. Parameter estimation in these linear mixed effect models were performed by maximizing the $\log$ likelihood function $(\log \mathrm{L})$. A general method for comparing nested models fit by maximum likelihood is the likelihood ratio test. And, one statistical model is said to be nested within another model if it represents a special case of the other model. The likelihood ratio test gives a p-value from a chi-square distribution. The following goodness of fit indicator was used; Bayesian information criterion (BIC). If we use BIC to compare the models, we prefer the model with the lowest BIC.

Primary, model (3) and (4) were adjusted by linear model. Then, Models (3) and (4) were run as mixed model with goat as random effect; we called now Models (5) and (6), respectively. Afterwards, mixed models included variance and correlation structure. The variance functions are specified in the lme function using the weight argument. The varPower was the variance weight used here which is a power of the absolute value of the variance covariate given by the fitted values. Correlation structure is used to model dependence among observations. The correlation structure used was an autoregressive structure of order 1 (corAR1). Therefore, Models (5) and (6) were converted to (7) and (8), respectively. Likelihood ratio test was used to model comparison and, plotting the residuals against predicted values was used for model diagnostics, and the quantile-quantile plot was used for normality test of residuals.

\section{Results and Discussion}

This work gathered data from eight studies and, observation across studies was not balanced. Considering the study effect as fixed effect while performing the regression analysis led to poorer adjust than when the study effect was considered as random. So, the goodness of fit indicators BIC was lower when the study was taken as random effect instead than fixed; 2740 vs 2757, respectively. And maximum $\log \mathrm{L}$ was greater with random than fixed study effect model (Table 2). Based on the BIC and $\log \mathrm{L}$ criteria, the model with study as random effect fitted the data better. Figure 1 illustrates the boxplot of energy balance for the eight studies adjusted for $\mathrm{Y}$, according to the mixed model corrected with study effect taken as random. Visual assessment suggests that the effect of MEI on the 
energy outputs were consistent across studies.

Table 3 shows the parameters estimates and goodness of fit from Moe [7] and

Table 2. Goodness of fit from the models used to correct the study effect.

\begin{tabular}{ccc}
\hline Model & BIC & $\log \mathrm{L}$ \\
\hline$(1)^{1}$ & 2757 & -1370 \\
$(2)^{2}$ & 2740 & -1350 \\
\hline
\end{tabular}

$\mathrm{BIC}=$ Bayesian information criterion; $\log \mathrm{L}=\log$ likelihood function. ${ }^{1}$ Linear model (1) $Y=\partial+S+X+\varepsilon$, Study $(S)$ as fixed effect; ${ }^{2}$ Linear model (2) $Y=\partial+S+X+\varepsilon$, Study $(S)$ as random effect.

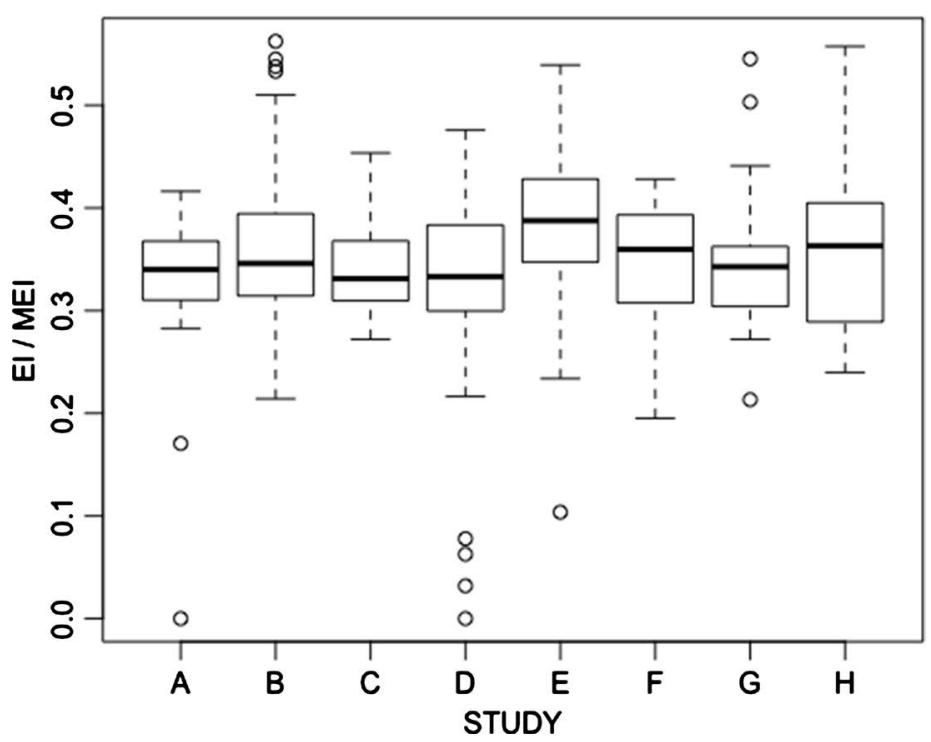

Figure 1. Boxplot of energy balance (EI/MEI) for the eight studies, on other hands, the linear mixed model. EIs energy in milk $\left(\mathrm{kJ} / \mathrm{kg} \mathrm{BW}{ }^{0.75}\right.$ and day); MEI, metabolic energy intake (kJ/kg BW ${ }^{0.75}$ and day). Study A (López and Fernández, 2013), B (López et al., 2014), C (Criscioni and Fernández, 2016), E (Ibáñez et al., 2016) and F, G, H (unpublished).

Table 3. Parameters estimates and goodness of fit.

\begin{tabular}{ccccccccc}
\hline MOE model $^{1}$ & $\beta_{0}$ & $\beta_{2}$ & $\beta_{3}$ & $\beta_{4}$ & BIC & $\operatorname{logL}$ & $\begin{array}{c}\operatorname{logL} \text { ratio } \\
\text { test (5) vs (7) }\end{array}$ & $p$-value \\
\hline$(3)$ & 531 & 1.41 & 1.32 & 1.21 & 2947.1 & -1459.6 & & \\
$(5)$ & 538 & 1.41 & 1.31 & 1.22 & 2939.3 & -1452.9 & & \\
$(7)$ & 544 & 1.40 & 1.30 & 1.22 & 2936.6 & -1446.0 & 13.87 & 0.001 \\
\hline STRATHE model & & & & & & & & \\
& $\beta_{0}$ & $\beta_{1}$ & $\beta_{2}$ & $\beta_{3}$ & BIC & $\operatorname{logL}$ & $\operatorname{logL}$ ratio & $p$-value \\
& 293 & 0.63 & 0.78 & 0.77 & 2732.1 & -1352.1 & & \\
$(4)$ & 296 & 0.63 & 0.77 & 0.77 & 2724.4 & -1345.4 & & \\
$(8)$ & 283 & 0.62 & 0.74 & 0.78 & 2720.9 & -1338.1 & 14.68 & 0.001 \\
\hline
\end{tabular}

$\mathrm{BIC}=$ Bayesian information criterion; $\log \mathrm{L}=\log$ likelihood function. ${ }^{1}$ Energy function proposed by Moe et al., $1971\left(\mathrm{MEI}=\beta_{0}+\beta_{2} \mathrm{El}+\beta_{3} \mathrm{Tg}+\beta_{4} \mathrm{Tl}+\varepsilon\right)$ : (3) linear; (5) mixed; (7) mixed with variance and correlation structure. ${ }^{2}$ Energy function proposed by Strathe et al., $2011\left(\mathrm{El}=\beta_{0}+\beta_{1} \mathrm{MEI}+\beta_{2} \mathrm{Tg}+\beta_{3} \mathrm{Tl}+\varepsilon\right)$ : (4) linear; (6) mixed; (8) mixed with variance and correlation structure. 
Strathe [8] models. Based on BIC criterion, energy balance data were better described by Models (7) than (5) and (3) for Moe and, for the Strathe model better fit with (8) than (6) and (4) were found. The Moe model had produced a value of $\log \mathrm{L}$ of $-1457,-1453$ and -1446 for (3), (5) and (7) respectively. Model (7) was considerably greater than (3) and (5). The likelihood ratio statistic comparing the mixed model with the mixed model than included correlation and a variance function was large (13.87) and the p-value for the test was essentially zero ( $p=$ 0.001 ), so we preferred Model (7). The Strathe model had produced a value of $\log \mathrm{L}$ of $-1352,-1345$ and -1338 for (4), (6) and (8) respectively. Because the larger likelihood ratio (14.68) and significant $(p<0.0001)$ differences for the test comparing Models (6) and (8), we found that Model (8) is significantly better than (6).

Figure 2 showed the standardized residual and quantile plots; for Moe and Strathe models. We presented only the model with better goodness of fit described in Table 3; Model (7) and (8). The residuals are symmetrically distributed around zero, with approximately constant variance. Figure 2 showed the normal plots of residuals by the quantile-quantile plot as well. Distribution of the within goat errors has heavier tails in both but is also symmetry around zero.

Consequently, BIC criterion was smaller for Strathe than Moe model. And, within Strathe model, smaller BIC and maximum $\log \mathrm{L}$ were found in (8) model than (4) and (6), with a larger likelihood ratio test. Thus, the goodness of fit indicated a preference for Model (8).

Efficiencies of conversion of ME to net energy, according to the two models tested, were shown in Table 4. Due to that better goodness of fit with (8) model, our discussion was based on those estimated parameters.

The NEm obtained from Model (8) was of $283 \mathrm{~kJ} / \mathrm{kg} \mathrm{BW}^{0.75}$ per day. Estimation of maintenance energy requirements of goats in the literature is scarce and, includes animals from different breeds in different physiological stages. Nine estimates of fasting heat production of adult goats were used by AFRC [2], ranged from 212 to $403 \mathrm{~kJ} \mathrm{NEm} / \mathrm{kg} \mathrm{BW}{ }^{0.75}$ per day. A mean value of $315 \mathrm{~kJ} \mathrm{NEm} / \mathrm{kg}$ $\mathrm{BW}^{0.75}$ per day was recommended by AFRC [2]. This is very similar to the value in ARC [20] of $319 \mathrm{~kJ} / \mathrm{kg} \mathrm{BW}^{0.75}$ for the fasting metabolism of adult cattle. Thus, the fasting metabolism of both cattle and goat appears to be higher than that of the sheep, for which ARC [20] gave values of $230 \mathrm{~kJ} / \mathrm{kg} \mathrm{BW}{ }^{0.75}$. On the other hand, the NRC [3] proposed the same value than AFRC [2] while the SRNS [4]

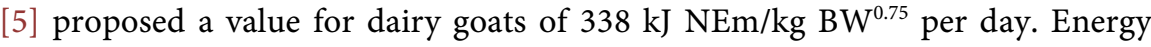
requirements of lactating dairy goats recommended by NRC [3] are based on the study of [21] involving a database of treatment from the literature, database that did not have in consideration factors such as dietary concentrate level. The INRA [6] system is based on material balance studies on goats in the descending phase of lactation, integrated with information obtained by the other feeding systems. The value proposed by INRA [6] was lower than our study; $265 \mathrm{~kJ} / \mathrm{kg}$ $\mathrm{BW}^{0.75}$ per day. Other studies conducted with Murciano-Granadina goats by 

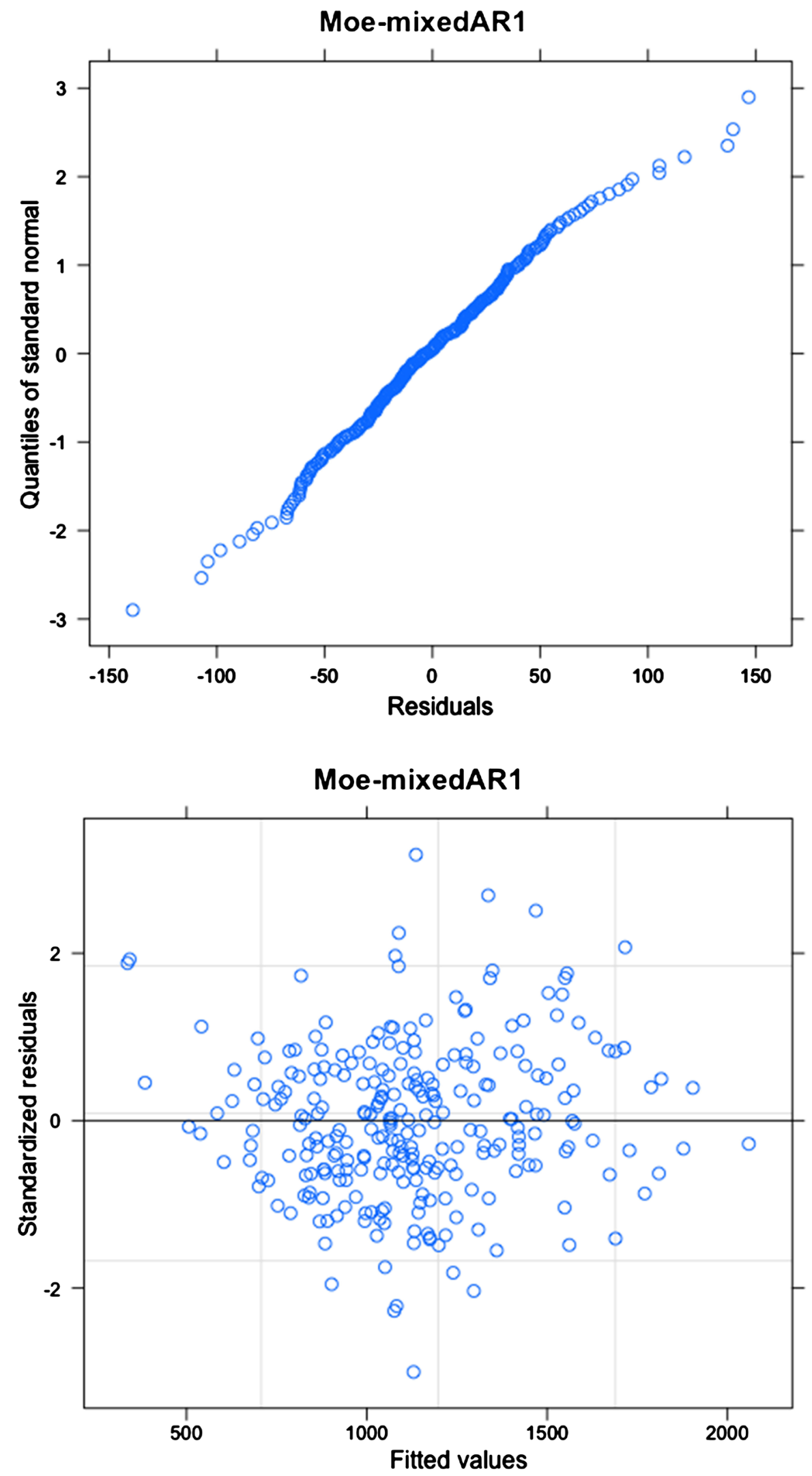

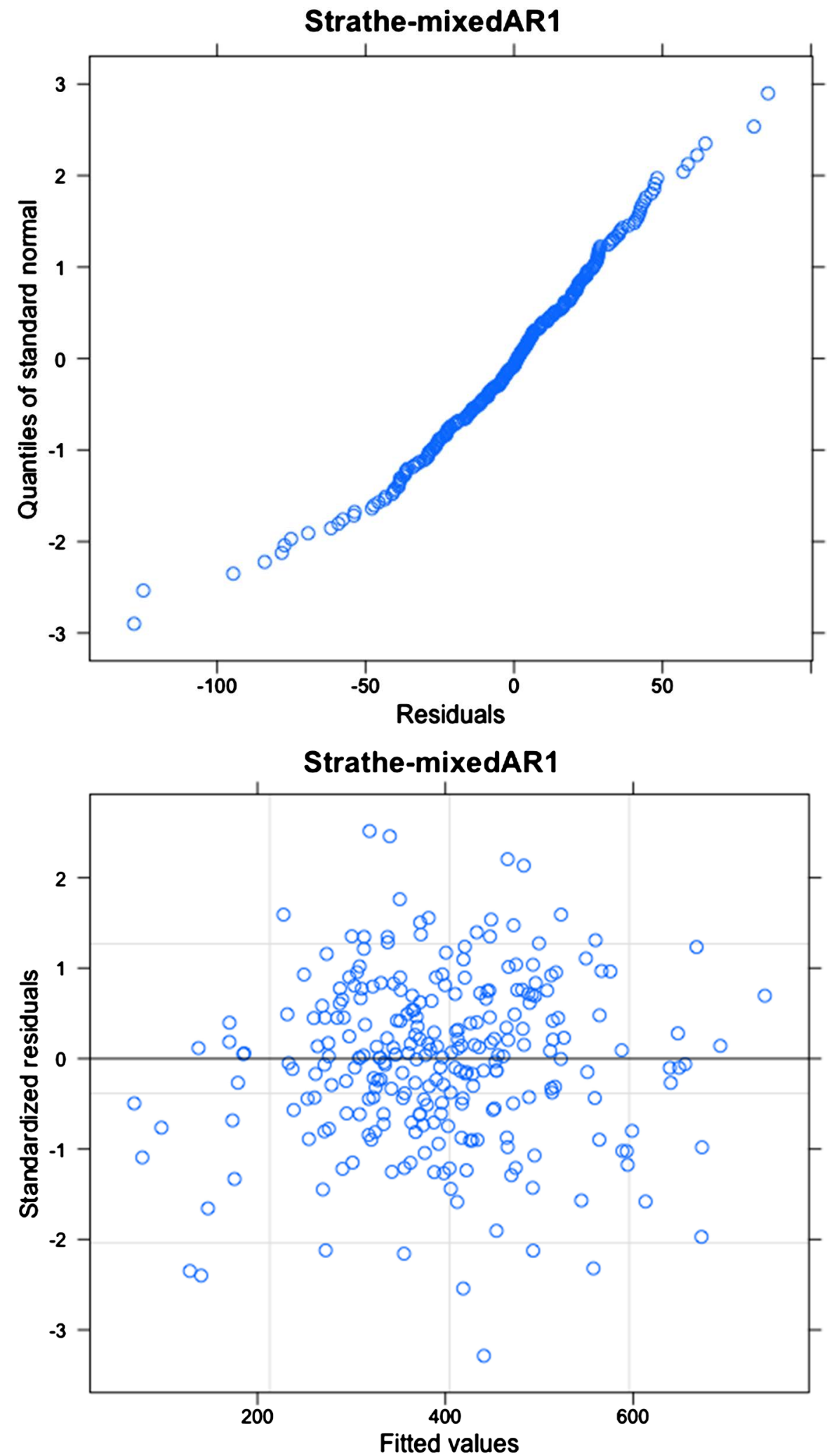

Figure 2. Diagnostics of the models proposed by Moe et al. (1971) $\quad\left[\mathrm{MEI}=\beta_{0}+\beta_{2} \mathrm{El}+\beta_{3} \mathrm{Tg}+\beta_{4} \mathrm{Tl}+\varepsilon\right]$ and Strathe et al. (2011) $\left[\mathrm{El}=\beta_{0}+\beta_{1} \mathrm{MEI}+\beta_{2} \mathrm{Tg}+\beta_{3} \mathrm{Tl}+\varepsilon\right]$, using a mixed model with autocorrelation structure of order 1 . Where MEI was the metabolizable energy intake, EI the net energy in milk and, $\beta_{0}, \beta_{1}, \beta_{2}$ and $\beta_{3}$ were the parameters, $\mathrm{Tg}$ was tissue energy retention and $\mathrm{Tl}$ the milk energy derived from body stores. 
Table 4. Energy parameters obtained in dairy goats.

\begin{tabular}{cccccc}
\hline${\text { MOE } \text { model }^{1}}^{\prime}$ & MEm & $k_{l}$ & $k_{g}$ & $k_{t}$ & NEm \\
\hline$(3)$ & 531 & 0.71 & 0.76 & 0.86 & \\
$(5)$ & 538 & 0.71 & 0.76 & 0.87 & \\
$(7)$ & 544 & 0.71 & 0.77 & 0.87 & \\
\hline STRATHE model & & & & & \\
\hline$(4)$ & 466 & 0.63 & 0.81 & 0.77 & 293 \\
$(6)$ & 470 & 0.63 & 0.82 & 0.77 & 296 \\
$(8)$ & 460 & 0.62 & 0.83 & 0.78 & 283 \\
\hline
\end{tabular}

MEm = metabolizable energy for maintenance $\left(\mathrm{kJ} / \mathrm{kgBW}^{0.75}\right) ; k_{l}=$ efficiency of use of ME for lactation; $k_{g}=$ efficiency of use of ME for gain; $k_{t}=$ efficiency tissue energy mobilization; NEm = net energy for maintenance $\left(\mathrm{kJ} / \mathrm{kgBW}^{0.75}\right)$. ${ }^{1}$ Energy function proposed by Moe et al., $1971\left(\mathrm{MEI}=\beta_{0}+\beta_{2} \mathrm{El}+\beta_{3} \mathrm{Tg}+\beta_{4} \mathrm{Tl}+\varepsilon\right)$ : (3) linear; (5) mixed; (7) mixed with variance and correlation structure. ${ }^{2}$ Energy function proposed by Strathe et al., 2011 ( $\mathrm{El}=\beta_{0}+\beta_{1} \mathrm{MEI}+\beta_{2} \mathrm{Tg}+\beta_{3} \mathrm{Tl}+\varepsilon$ ): (4) linear; (6) mixed; (8) mixed with variance and correlation structure.

[22], reported a value of $324 \mathrm{~kJ} / \mathrm{kg} \mathrm{BW} \mathrm{BW}^{0.75}$ per day, greater than the value obtained at the present work, but we must indicate that these authors used castrate males for the calculation. [23], with the same goat breed than our work but 27 years before, estimated the ENm during lactation by regression and obtained a value of $268 \mathrm{~kJ} / \mathrm{kg} \mathrm{BW} \mathrm{BW}^{0.75}$ per day, slightly lower than our value obtained with Model (8). [15] found a fasting heat production of $310 \mathrm{~kJ} / \mathrm{kg} \mathrm{BW}^{0.75}$ per day, obtained by indirect calorimetry in female's Murciano-Granadina dry goat. The MEm obtained with (8) model was $460 \mathrm{~kJ} / \mathrm{kg} \mathrm{BW}^{0.75}$ per day. Seventeen estimates of the MEm of goat derived from feeding trials were found by AFRC [2], and the average value proposed was $438 \mathrm{~kJ} / \mathrm{kg} \mathrm{BW}^{0.75}$ per day. According to literature, the variation between estimates was considerable; ranged from 365 to $530 \mathrm{~kJ} / \mathrm{kg}$ $\mathrm{BW}^{0.75}$ per day. So, [24] estimated MEm from several energy metabolism studies conducted with goats, and it varies widely; from 422 to $501 \mathrm{~kJ} / \mathrm{kg} \mathrm{BW}^{0.75}$ per day. The NRC [3] for goats, adopted [24] estimated maintenance requirements, which they were obtained for three breed groups (dairy, meat and indigenous, and Angora goats) and various animal categories (growing animals, dry animals and wethers, lactating goats, intact males). INRA [6] with a qm (ME to gross energy in the diet) of 0.64 recommended $441 \mathrm{~kJ} / \mathrm{kg} \mathrm{BW}{ }^{0.75}$ per day, value 19 $\mathrm{kJ} / \mathrm{kg} \mathrm{BW} \mathrm{B}^{0.75}$ per day lower than the value estimated in this study. [22] obtained a value of $443 \mathrm{~kJ} \mathrm{MEm} / \mathrm{kg} \mathrm{BW}^{0.75}$ per day with adult castrated males' goats and [23] obtained a value of $401 \mathrm{~kJ} / \mathrm{kg} \mathrm{BW}{ }^{0.75}$ per day, both authors using indirect calorimetry and regression techniques. [25] reported, in cow of high genetic merit, higher gross energy efficiency than cows of low genetic merit. Concomitantly, genetic selection has increased fasting heat production and energy maintenance requirements in lactating cows [26] because genetic selection chose leaner animals (larger proportions of body protein mass, enlarged organ size and lower backfat thickness) than fatter. Bigger organ size means greater energy expendi- 
ture to sustain transport, digestion and absorption. Therefore, the increase in maintenance requirements found in our work was consistent with the literature that describes increased fasting heat production in animals of higher genetic merit (for instance, genetic merit improved from the previous study of [15] [23].

Differences in ME requirements for milk production are due to variations in the conversion efficiency from $\mathrm{ME}$ to $\mathrm{NE}$, depending on whether the energy comes from feed or body fat mobilization. Our work shown a $k_{l}$ value of $62 \%$, within the range of the feeding system reported below. The $k_{l}$ used by AFRC [2] and NRC [3] was $63 \%$ and $61 \%$, respectively (with a qm of 0.64 from our database). The SRNS for goats [4] [5] proposed a value of 64\%. INRA [6] proposed an efficiency of ME to milk only that included maintenance $\left(k_{l s}\right)$, and this efficiency for a qm of 0.64 was $65 \%$. [23] proposed a $k_{l}$ of $67 \%$, which is very similar to those suggested by INRA [6] for high-quality diets. [27] found an average $k_{l}$ value of $67 \%$ for Saanen goat fed silage-based forage diet and non-forage diet in mid lactation. And [28] fed Alpine goats during mid lactation with $60 \%$ of concentrate found a $k_{l}$ of $63 \%$.

Interpreting BW changes is often difficult because of the related variations in volume and content of the digestive tract system. The AFRC [2] method deals with BW changes only for growing animals and lactating goats. AFRC considers a $k_{g}$ value of $60 \%$ and, the conversion efficiency of NE from body reserves to milk production was $84 \%$, which is slightly higher than that of INRA $\left(k_{t g}=80 \%\right)$. For INRA [6], the efficiency of ME to store energy reserves $\left(k_{t g}\right)$ is significantly higher with a difference with $k_{l s}$ which is almost constant; therefore, it is calculated from $k_{l s}\left(k_{t g}=k_{l s}+15=80 \%\right)$. The NRC [3] proposed a $k_{g}$ value of $70 \%$ and adopted the efficiency of mobilization NE to milk production (El) equal to the $84 \%$, values proposed by ARC [20]. The $k_{g}$ value obtained in our study (83\%) was similar than INRA [6] and greater than NRC [3]. The efficiency $k_{t}$ was $78 \%$, lower than the main feeding systems discussed here, although INRA [6] proposed that the $k_{t g}$ was also the efficiency of utilization of body energy reserve for lactation (80\%), similar that the value obtained with our model.

All feeding system reviewed here for dairy goats shown $k_{t}$ greater than $k_{g}$ in our study it was opposed and, INRA [6] gave the same value for $k_{t}$ and $k_{g}$, and close to our model. If we moved to dairy cow's literature we found the same results from [29] where $k_{g}$ was greater than $k_{t}$. [30] discussed this topic in their paper, suggested that in US Holstein cows, the efficiency of producing milk from body store reserves is substantially higher than the efficiency of utilizing dietary ME for tissue energy gain, as initially proposed by [7]. [30] suggested that body growth was limited and hypothesized that the higher $k_{g}$ in comparison with values from [7], was a consequence of the gain being mostly replenishment of body lipids mobilized at early lactation. Therefore, differences in $k_{g}$ by [30] may be a result of the gain composition and different degrees of cattle maturity at the start of lactation. In our study, goats were in mid and mid-late lactation suggesting than both, $k_{g}$ and $k_{t}$, could be not constant during lactation, showing 
variation from early though mid to late lactation. Peak lactation is accomplished with lipid mobilization whereas that mid to late lactation favoring the utilization of metabolic fuels for body reserves recovery rather than milk production.

Likewise, $k_{g}$ is theoretically affected by the diet composition and differences in the nutrient fractions comprising dietary ME have the potential to alter the efficiency of dietary energy utilization. The increase in the efficiency of utilizing dietary energy could be partially attributed to the changes in diet composition (from forage diets to mixed diets with dietary ether extract levels higher and increased amount of cereals). During the last 30 years, dairy goat feeding systems in Spain have passed from grazing to have the animals confined on the barn, feeding with mixed diets rich in concentrates; mainly cereals and increasing the amount of fat added too [31]. Table 1 summarized that starch ranged from $1.5 \%$ to $41.6 \%$ and EE ranged from $1.9 \%$ to $5.7 \%$ in mixed diets used in this compilation. The composition of a diet can shift the microbial population in the rumen and consequence of the production of volatile fatty acids. The rumen volatile fatty acids can alter energy partition between milk and body tissue; molar proportions of acetic and butyric acids are positively related to milk fat concentration and, as indicated [26] in their review, increasing propionic acid proportion can result in more energy partitioned into body tissue and less into milk. Furthermore, changing diet composition can influence partitioning of nutrients towards body tissues rather than mammary gland. In an investigation of the effect of lipogenic and glucogenic feeds on nutrient partitioning and energy balance, [32] showed that cows fed a lipogenic diet partitioned more energy to milk than cows fed a glucogenic diet. The energy mobilized from body fat tended to be higher in cows fed a lipogenic diet than cows fed the glucogenic diet. Lipogenic nutrients originate either from fibre or dairy fat or from body reserves while glucogenic nutrients originate from starch escaped from rumen degradation or gluconeogenesis. Our study used mixed diets based on cereal suggesting that glucogenic nutrients stimulate body fat deposition and the partitioning of ME into body tissues. When the mixed diets replaced cereal with fibrous by product, greater fat was added to reach isoenergetic diets and, consequently, the lipogenic nutrients increased. However, no effect on efficiencies was found, probably since that dietary fat decrease the heat increment due that the relatively low energy cost of the transfer of absorbed fatty acids to milk when compared with the cost of the novo synthesis of fatty acids [30]. These discovered, in common with the stage of lactation, could explain the higher $k_{g}$ than $k_{t}$ observed in our study, agreeing with the efficiencies proposed by [30]. Likewise, INRA [6] proposed the same value of $k_{g}$ and $k_{i} k_{t g}=80 \%$, being this value the average between $k_{g}(83 \%)$ and $k_{t}(78 \%)$ obtained in our study.

\section{Conclusion}

Two models were proposed to analyze energy balance data from lactating goats fed mid and mid-late lactation; Moe [7] and Strathe [8]. The better fitted was 
obtained with Strathe model and NEm was $283 \mathrm{~kJ} / \mathrm{kg} \mathrm{BW}{ }^{0.75}$ per day, and $k_{b} k_{g}$ and $k_{t}$ were $62 \%, 83 \%$ and $78 \%$, respectively. The increase in the efficiency of utilizing dietary energy for gain was partially attributed to the stage of lactation (mid-late) and the use of cereal in the mixed diets.

\section{Conflicts of Interest}

The authors declare no conflicts of interest regarding the publication of this paper.

\section{References}

[1] Jørgensen, S.E. (2015) New Method to Calculate the Work Energy of Information and Organisms. Ecological Modelling, 295, 18-20.

https://doi.org/10.1016/j.ecolmodel.2014.09.001

[2] Agricultural and Food Research Council (AFRC) (1998) The Nutrition of Goats. Technical Committee on Response to Nutrients. Report Number 10. CAB International, Wallingford.

[3] National Research Council (NRC) (2007) Nutrient Requirements of Small Ruminants. Sheep, Goats, Cervids and New World Camelids. National Academy Press, Washington DC.

[4] Cannas, A., Atzori, A.S., Boe, F. and Teixeira, I.A.M.A. (2008) Energy and Protein Requirements of Goats. In: Cannas, A. and Pulina, G., Eds., Dairy Goats, Feeding and Nutrition, CAB International, Cambridge, 118-146. https://doi.org/10.1079/9781845933487.0118

[5] Tedeschi, L.O., Cannas, A. and Fox, D.G. (2010) A Nutrition Mathematical Model to Account for Dietary Supply and Requirements of Energy and Other Nutrients for Domesticated Small Ruminants: The Development and Evaluation of the Small Ruminant Nutrition System. Small Ruminant Research, 89, 174-184.

https://doi.org/10.1016/j.smallrumres.2009.12.041

[6] Institute Nationale Recherche Agronomique (INRA) (2018) Feeding System for Ruminants. Wageningen Academic Publishers, Wageningen.

[7] Moe, P.W., Tyrrell, H.F. and Flatt, W.P. (1971) Energetics of Body Tissue Mobilization. Journal of Dairy Science Dairy, 54, 548-553. https://doi.org/10.3168/jds.S0022-0302(71)85886-1

[8] Strathe, A.B., Dijkstra, J., France, J., López, S., Yan, T. and Kebreab, E. (2011) A Bayesian Approach to Analyse Energy Balance Data from Lactating Dairy Cows. Journal of Dairy Science, 94, 2520-2531. https://doi.org/10.3168/jds.2010-3836

[9] European Union. European Directive 86/609 (2007) Commission Recommendations of 18 June 2007 on Guidelines for the Accommodation and Care of Animals Used for Experimental and Other Scientific Purposes. Annex II to European Council Directive 86/609. The Commission of the European Communities Publishing, Brussels.

[10] López, M.C. and Fernández, C. (2013) Energy Partitioning and Substrate Oxidation by Murciano-Granadina Goats during Mid Lactation Fed Soy Hulls and Corn Gluten Feed Blend as a Replacement for Corn Grain. Journal of Dairy Science, 96, 4542-4552. https://doi.org/10.3168/jds.2012-6473

[11] López, M.C., Estellés, F., Moya, V.J. and Fernández, C. (2014) Use of Dry Citrus Pulp or Soybean Hulls as a Replacement for Corn and Grain in Energy and Nitro- 
gen Partitioning, Methane Emissions and Milk Performance in Lactating Murciano-Granadina Goats. Journal of Dairy Science, 97, 7821-7832. https://doi.org/10.3168/jds.2014-8424

[12] Criscioni, P. and Fernández, C. (2016) Effect of Rice Bran as a Replacement for Oat Grain in Energy and Nitrogen Balance, Methane Emissions, and Milk Performance of Murciano-Granadina Goats. Journal of Dairy Science, 99, 280-290. https://doi.org/10.3168/jds.2015-9472

[13] Criscioni, P., Martí, J.V., Pérez-Baena, I., Palomares, J.L., Larsen, T. and Fernández, C. (2016) Replacement of Alfalfa Hay with Maralfalfa Hay in Diets of Lactating Dairy Goats. Animal Feed Science and Technology, 219, 1-12. https://doi.org/10.1016/j.anifeedsci.2016.05.020

[14] Ibáñez, C., Criscioni, P., Arriaga, H., Merino, P., Espinós, F.J. and Fernández, C. (2016) Murciano-Granadina Goat Performance and Methane Emission after Replacing Barley Grain with Fibrous by Products. PLOS ONE, 11, e0151215.

https://doi.org/10.1371/journal.pone.0151215

[15] Fernández, C., López, M.C. and Lachica, M. (2012) Description and Function of a Mobile Open-Circuit Respirometry System to Measure Gas Exchange in Small Ruminants. Animal Feed Science and Technology, 172, 242-246. https://doi.org/10.1016/j.anifeedsci.2012.01.006

[16] Fernández, C., López, M.C. and Lachica, M. (2015) Low Cost Open-Circuit Hood System for Measuring Gs Exchange in Small Ruminants: From Manual to Automatic Recording. Journal of Agricultural Science, 153, 1302-1309. https://doi.org/10.1017/S0021859615000416

[17] St-Pierre, N.R. (2001) Invited Review: Integrating Quantitative Findings for Multiple Studies Using Mixed Model Methodology. Journal of Dairy Science, 84, 741-755. https://doi.org/10.3168/jds.S0022-0302(01)74530-4

[18] Sauvant, D., Schmidely, P., Daudin, J.J. and St-Pierre, N.R. (2008) Meta Analyses of Experimental Data in Animal Nutrition. Animal, 2, 1203-1214. https://doi.org/10.1017/S1751731108002280

[19] R Core Team. (2016) R: A Language and Environment for Statistical Computing. R Foundation for Statistical Computing, Vienna.

[20] Agricultural Research Council (ARC) (1980) The Nutrient Requirements of Ruminant Livestock. Technical Revision of the Agricultural Research Council Working Party. Commonwealth Agricultural Bureaux, Farnham Royal.

[21] Nsahlai, I.V., Goetsch, A.L., Luo, J., Johnson, Z.B., Moore, J.E., Sahlu, T., Ferrell, C.L., Galyean, M.L. and Owens, F.N. (2004) Energy Requirements for Lactation of Goats. Small Ruminant Research, 53, 253-274. https://doi.org/10.1016/j.smallrumres.2004.04.007

[22] Prieto, C., Aguilera, J.F., Lara, L. and Fonollá, J. (1990) Protein and Energy Requirements for Maintenance of Indigenous Granadina Goats. British Journal of $\mathrm{Nu}$ trition, 63, 155-163. https://doi.org/10.1079/BJN19900103

[23] Aguilera, J.F., Prieto, C. and Fonollá, J. (1990) Protein and Energy Metabolism of Lactating Granadina Goats. British Journal of Nutrition, 63, 165-175. https://doi.org/10.1079/BJN19900104

[24] Luo, J., Goetsch, A.L., Nsahlai, I.V., Johnson, Z.B., Sahlu, T., Moore, J.E., Ferrell, C.L., Galyean, M.L. and Owens, F.N. (2004) Maintenance Energy Requirements of Goats: Predictions Based on Observations of Heat and Recovered Energy. Small Ruminant Research, 53, 221-230. https://doi.org/10.1016/j.smallrumres.2004.04.009

[25] Veerkamp, R.F. and Emmans, G.C. (1995) Sources of Genetic Variation in Energet- 
ic Efficiency of Dairy Cows. Livestock Production Science, 44, 87-97. https://doi.org/10.1016/0301-6226(95)00065-0

[26] Agnew, R.E. and Yan, T. (2000) Impact of Recent Research on Energy Feeding Systems for Dairy Cattle. Livestock Production Science, 66, 197-215. https://doi.org/10.1016/S0301-6226(00)00161-5

[27] Bava, L., Rapetti, L., Crovetto, G.M., Tamburini, A., Sandrucci, A., Galassi, G. and Succi, G. (2001) Effect of a Non-Forage Diet on Milk Production, Energy and Nitrogen Metabolism in Dairy Goats throughout Lactation. Journal of Dairy Science, 84, 2450-2459. https://doi.org/10.3168/jds.S0022-0302(01)74695-4

[28] Tovar-Luna, I., Puchala, R., Sahlu, T., Freetly, H.C. and Goetsch, A.L. (2010) Effects of Stage of Lactation and Dietary Concentrate Level on Energy Utilization by Alpine Dairy Goats. Journal of Dairy Science, 93, 4818-4828.

https://doi.org/10.3168/jds.2010-3315

[29] Kebreab, E., France, J., Agnew, E.E., Yan, T., Dijkstra, J., Beever, D.E. and Reynols, C.K. (2003) Alternatives to Linear Analysis of Energy Balance Data form Lactating Dairy Cows. Journal of Dairy Science, 86, 2904-2913. https://doi.org/10.3168/jds.S0022-0302(03)73887-9

[30] Moraes, L.E., Kebreab, E., Strathe, A.B., Dijkstra, J., France, J., Casper, D.P. and Fadel, J.G. (2015) Multivariate and Univariate Analysis of Energy Balance Data from Lactating Dairy Cows. Journal of Dairy Science, 98, 4012-4029. https://doi.org/10.3168/jds.2014-8995

[31] Daza, A., Fernández, C. and Sánchez, A. (2004) Ganado Caprino; producción, alimentación y sanidad. Editorial Agrícola Española S.A. 28013, Madrid.

[32] Van Knegsel, A.T.M., Van den Brand, H., Dijkstra, J., Van Straalen, W.M., Heetkamp, M.J., Tamminga, S. and Kemp, B. (2007) Dietary Energy Source in Dairy Cows in Early Lactation: Energy Partitioning and Milk Composition. Journal of Dairy Science, 90, 1467-1476. https://doi.org/10.3168/jds.S0022-0302(07)71632-6 